\title{
Saccharification and Ethanol Production from Chlorella sp. Through High Speed Extrusion Pretreatment
}

\author{
Choon Geun Lee ${ }^{1}$, Woon Yong Choi ${ }^{1}$, Yong Chang Seo ${ }^{1}$, Chi Ho Song ${ }^{1}$, Ju Hee Ahn ${ }^{1}$, Kyung Hwan Jung ${ }^{2}$, \\ Sang Eun Lee ${ }^{2}$, Do Hyung Kang ${ }^{3}$, and Hyeon Yong Lee ${ }^{4}$ *
}

접수: 2012년 6월 15일 / 게재승인: 2012년 6월 27일

(C) 2012 The Korean Society for Biotechnology and Bioengineering

\begin{abstract}
Among various pretreatment processes for bioethanol production, extrusion pretreatment, one of cheap and simple process was investigated to efficiently produce fermentable sugars from micro alga, Chlorella sp. The biomass was pretreated in a single screw extruder at five different barrel temperatures of $45,50,55,60$ and $65^{\circ} \mathrm{C}$, respectively with five screw rotation speed of 10, 50, 100, 150 and $200 \mathrm{rpm}$. The pretreated biomass was reacted with two different hydrolyzing enzymes of cellulase and amyloglucosidase since the biomass contained different types of carbohydrates, compared to cellulose of agricultural by-products such wheat and corn stovers, etc. In general, higher glucose conversion yield was obtained as $13.24(\%, w / w)$ at $55^{\circ} \mathrm{C}$ of barrel temperature and $100 \mathrm{rpm}$ of screw speed conditions. In treating $5 \mathrm{FPU} /$ glucan of cellulase and $150 \mathrm{Unit} / \mathrm{mL}$ of amyloglucosidase, ca. $64 \%$ of cellulose and $40 \%$ of

\footnotetext{
${ }^{1}$ 강원대학교 의생명과학대학 의생명소재공학과

${ }^{1}$ Department of Biomedical Materials Engineering, Kangwon National University, Chuncheon 200-701, Korea

2한국교통대학교 보건생명대학 생명공학과

${ }^{2}$ Department of Biotechnology, Korea National University of Transportation, Chungbuk 368-701, Korea

${ }^{3}$ 한국해양과학기술원

${ }^{3}$ Korea Institute of Ocean Science \& Technology (KIOST), Ansan P.O. Box 29, Seoul 426-744, Korea

${ }^{4}$ 서원대학교 식품과학부 차학과

${ }^{4}$ Department of Teaics, Seowon University, Cheongju 361-742, Korea

Tel: +82-43-299-8471, Fax: +82-43-299-8470

e-mail:hyeonl@seowon.ac.kr
}

polysaccharides in the micro alga were converted into glucose, which was higher yields than those from other reported data without applying an extrusion process. $84 \%$ of the fermentable sugars obtained from the hyrolyzing processes were fermented into ethanol in considering $50 \%$ of theoretical maximum fermentation yield of the yeast. These results implied that high speed extrusion could be suitable as a pretreatment process for the production of bioethanol from Chlorella sp.

Keywords: Extruder, Pretreatment, Bioethanol, Microalgae, Enzyme treatment

\section{1. 서론}

화석연료의 무분별한 사용에 의한 환경적인 피해와 피할 수 없는 화석연료의 고갈로 인해 전 세계적으로 신 재생에너지 개발을 위한 연구가 시급한 실정이다. 그 중에서도 화석 연료 중 인류가 가장 많이 사용하는 가솔린을 대체할 수 있는 바 이오 에탄올에 관한 연구가 활발하다 [1,2]. 특히, 최근 바이 오 에탄올 연구의 초점은 해양바이오매스를 이용하여 연료를 생산하는 기술 개발이 활발하다 [3].

그중에서도 미세조류는 단세포부터 다세포까지 다양한 형태로 전 세계적으로 다양한 종이 존재하고, 최근에는 $\mathrm{CO}_{2}$ 감축효과와 더불어 미래의 바이오 연료의 생산을 위한 차세 대 바이오매스로 주목 받고 있다 [4]. 특히, 전 세계에 광범위 하게 자생하는 녹조류인 Chlorella sp.는 생육속도가 빠르고, 높은 광합성 효율을 나타내며, 세포내 지질 성분 및 다당류의 함량이 많아 곡류 및 목재류와 같은 1,2 세대 바이오매스보다 
에너지 효율이 높은 이점을 바탕으로 하여, 3 세대 바이오매 스로 주목받고 있다 [5-9].

하지만, 3 세대 바이오매스를 이용한 바이오 에너지 생산 은 미세조류를 이용한 바이오 에탄올 생산보다는 주로 바이 오 디젤의 생산이 더 활발하게 진행되고 있다. Chlorella $\mathrm{sp.}$ 는 생육 환경에 따라 세포 내 구성 성분의 비율을 변화시킬 수 있는데, 이러한 특징을 살려 배양 공정 변수의 조절을 통해 세포 내 지질 함량을 증진시키고, 이를 추출하여 바이오 디 젤 생산하는 연구가 주를 이루고 있다. 하지만 Chlorella sp. 는 지질을 많이 함유하고 있을 뿐만 아니라 바이오 에탄올 생산이 가능한 당 성분 또한 다량 함유하고 있기 때문에 바 이오 에탄올 생산 또한 가능하다.

Table 1을 통해 알 수 있듯이 Chlorella sp.는 단단한 세 포벽 (rigid cell wall)을 구성하는 성분인 셀룰로오스가 약 $35.28(\%, \mathrm{w} / \mathrm{w})$ 가 함유되어 있으며, 세포벽으로 둘러싸인 세포내에 저장되어 있는 다당류인 전분은 $20.52(\%, \mathrm{w} / \mathrm{w})$ 로 구성되어있다. 하지만 Chlorella sp.의 세포벽구조는 세포벽 외층 (outer cell wall layer)과 세포벽내층 (inner cell wall layer)의 두 층으로 구성되어있고 그 중 세포벽외층은 혼합 다중층의 형태로 셀룰로오스를 포함하는 3 중구조(trilaminar structure)로 구성되어있어 세포벽의 구조가 매우 단단하고, 외부의 힘에 대해 강한 저항력를 갖고 있기 때문에 강한 물 리적, 화학적 전처리 과정을 거치지 않고서는 세포벽에 다량 으로 존재하는 셀룰로오스나 세포내에 주로 저장되어 있는 전분으로부터 바이오 에탄올 생산이 가능한 글루코오스로의 전환에는 어려움이 따른다 [10-13]. 따라서, Chlorella sp.를 구성하는 셀룰로오스, 전분 등 다당류 성분을 단당류로 전환 시키기 위해서는 혼합 다중층으로 단단하게 구성된 세포벽의 파쇄하기 위한 전처리 공정이 우선적으로 실시되어야 한다.

Table 1. The polysaccharide composition in Chlorella sp.

\begin{tabular}{lc}
\hline \multirow{2}{*}{ Total Carbohydrate } & Composition $(\%, \mathrm{w} / \mathrm{w})$ \\
\cline { 2 - 2 } & 21.25 \\
\hline Starch & 20.52 \\
Cellulose & 35.28 \\
Hemicellulose & 10.19 \\
\hline
\end{tabular}

일반적으로 바이오 에탄올 생산에 있어서 시료로부터 당 성분의 추출을 위한 전처리 공정은 매우 중요한 공정 중 하 나이며, 가수분해 전처리 공정은 주로 화학적, 물리적 방법 이 대부분이다. 이러한 전처리 방법들은 곡류 및 목질계 바 이오매스의 다당류로부터 단당류로의 전환 시에 주로 사용 되어져 왔다. 특히, 목질계 바이오매스는 강한 결합력을 갖는 리그닌 함량이 높아 세포벽의 결정도가 높기 때문에 황산, 염산 등과 같은 강산이나 강염기의 화학적 물질이나 고온, 고압 조건의 물리적 힘을 가하여 리그닌 구조의 파쇄를 유도 함으로써 단당류를 얻는 공정이 주를 이루었다. 하지만 산/ 염기 전처리 공정의 경우, 전처리 후 중화 공정이 요구되며, 이에 따른 추가비용과 공정 시간의 소비로 인해 환경적, 경제 적 문제를 야기한다. 또, 산/염기와 같은 화학적 물질의 사용 과 물리적으로 높은 온도와 압력을 적용할 경우 발효저해물
질 5-hydroxy methylfurfural (HMF)의 생성으로 인하여 후 속 공정인 에탄올 발효 공정에서 효모의 활성이 저해되기 때문에 글루코오스로부터 에탄올 발효 효율이 낮아지게 된 다 [14-17]. 반면, 미세조류는 세포벽을 구성하는 성분 중 리그닌 성분의 함량이 낮아 산/염기 전처리에 따른 후속 공 정인 중화 과정을 추가적으로 실시하지 않아 공정비용과 공 정에 소비되는 시간을 줄일 수 있다. 게다가 저렴한 공정비용 으로 고효율의 당화물을 얻을 수 있고, 산/염기와 같은 화학 물질과 고온, 고압의 공정 변수를 적용으로 인해 발생하는 발효저해물질 (HMF)의 생성을 줄일 수 있어 바이오 에탄올 생산에 유리한 바이오매스로 판단된다 [18-21].

따라서, 화학적 물질을 사용하지 않고 강한 물리적 에너지 만을 이용하여 공정 시간을 단축하면서도 발효가능한 당으로 의 전환 효율이 우수한 전처리 공정의 개발이 필요하다 [22]. 하지만 물만을 이용한 기존의 전처리 공정은 산/염기를 이 용하는 화학적 전처리 공정보다 단당류를 당화시키는 효율이 높지 않아 글루코오스 전환 수율이 낮고, 물리적 전처리 공 정의 적용에도 불구하고 글루코오스 전환에 필요한 에너지 소비의 증가와 전처리 공정 시간의 과잉 소비로 인해 공정 에 소비되는 비용의 증가로 경제성이 낮아지기 때문에 물을 이용하면서도 당 전환 수율이 높고, 전처리 공정에 소비되 는 에너지 및 시간을 감축시킬 수 있는 새로운 전처리 공정 의 도입이 필수적이다 $[23,24]$.

고속 압출 공정은 압출기 스크루의 회전운동 시 발생하는 마찰력과 고전단력 (shearing force) 및 배럴 온도의 최적 화를 통해 미세조류가 갖는 혼합 다중층 세포벽 골격을 이 루는 셀룰로오스를 파쇄하여 단당류의 형태로 전환할 수 있 으며, 세포벽의 파쇄에 따른 세포내 저장 다당류들의 용출 을 유도할 수 있다. 그러나, 전처리 공정을 통해 모든 다당 류들의 단당류로의 전환은 불가능하며, 이를 추가적으로 파 쇄하기 위해서 효소처리공정을 적용해 단당류 전환 수율을 증진시킬 수 있다. 또, 오직 물만을 사용하고, 황산 전처리 공정에 비해 낮은 온도를 설정하여 전처리 공정을 진행함으 로써, 발효저해물질의 생성량을 감소시킬 수 있기 때문에 Saccharomyces cerevisiae를 이용한 에탄올 발효 수율의 증 진을 도모할 수 있을 것으로 사료된다.

따라서, Chlorella sp.의 혼합 다중층으로 구성된 단단한 세포벽을 구성하는 셀룰로오스와 세포내에 저장된 다당류 인 전분을 단당류로의 전환하는 공정에서 세포내로 물의 출 입이 용이해져 세포내에 존재하는 당화성분들의 용출이 빠 른 시간에 가능하며, 낮은 에너지의 소비량과 더불어 오직 물만을 사용하는 전처리 공정을 적용하여 추출 효율을 증진 시킬 수 있는 고속 압출 전처리 공정을 적용한 바이오 에탄올 생산에 관한 연구를 실시하였다 $[25,26]$.

\section{2. 재료 및 방법}

\section{1. 실험재료}

본 실험의 균주는 Chlorella sp.를 사용하였으며, 한국해양미 세조류은행에서 분양받아 f/2 배지에서 배양하였다. $F / 2$ 배 
지의 조성은 다음과 같다. $29.23 \mathrm{~g} \mathrm{NaCl}, 1.105 \mathrm{~g} \mathrm{KCl}, 11.09 \mathrm{~g}$ $\mathrm{MgSO}_{4} \cdot 7 \mathrm{H}_{2} \mathrm{O}, 1.21 \mathrm{~g}$ Tris-base, $1.83 \mathrm{~g} \mathrm{CaCl}_{2} \cdot 2 \mathrm{H}_{2} \mathrm{O}, 0.25 \mathrm{~g}$ $\mathrm{NaHCO}_{3}, 3.0 \mathrm{~mL}$ trace metal solution을 해수 $1 \mathrm{~L}$ 에 용해시 켜 배양 배지로 사용하였다 [27]. Trace metal solution은 $281.3 \mathrm{mg} \mathrm{NaNO}$, $21.2 \mathrm{mg} \mathrm{NaH} \mathrm{PO}_{4} \cdot \mathrm{H}_{2} \mathrm{O}, 16.35 \mathrm{mg} \mathrm{Na}_{2}$. EDTA, $11.8 \mathrm{mg} \mathrm{FeCl}{ }_{3} \cdot 6 \mathrm{H}_{2} \mathrm{O}, 675 \mu \mathrm{gnCl}_{2} \cdot 4 \mathrm{H}_{2} \mathrm{O}, 37.5 \mu \mathrm{g}$ $\mathrm{CoCl}_{2} \cdot 6 \mathrm{H}_{2} \mathrm{O}, 37.5 \mu \mathrm{g} \mathrm{ZnSO} \cdot \cdot 7 \mathrm{H}_{2} \mathrm{O}, 22.5 \mu \mathrm{g} \mathrm{Na} 2 \mathrm{MoO}_{4}$, $0.375 \mathrm{mg}$ vitamin $\mathrm{B}_{1}, 0.188 \mu \mathrm{g}$ biotin으로 구성하였다. 제조된 $\mathrm{f} / 2$ 배지는 $121^{\circ} \mathrm{C}$ 에서 15 분간 고압멸균기 (한국기기제작 HK-AC120, Korea)를 이용하여 가압 멸균하였으며, $0.45 \mu \mathrm{m}$ 여과지 (Watman, No. 1, England)를 통해 여과하여 이용하였 다. 배양한 균체를 원심분리 $(3000 \mathrm{rpm}, 10 \mathrm{~min})$ 하여 상층 배 지를 제거한 후 하층의 균체만을 얻어 동결건조 시킨 후 시료 는 밀봉하여 $4^{\circ} \mathrm{C}$ 냉장실에 보관하면서 실험에 사용하였다.

\section{2. 고속압출기를 이용한 Chlorella sp.의 가수분해}

본 실험에서 사용한 압출기 (Hackensack, PL2000, USA)의 스크류 직경은 $29 \mathrm{~mm}$, 직경과 길이의 비는 $25: 1$ 이고, 사 출구의 직경은 $3 \mathrm{~mm}$ 이었다. 고속압출기는 시료를 주입하는 원료투입구, 스크루 (screw)의 강한 회전에 의한 전단응력이 작용하고 다양한 온도설정이 가능한 배럴 그리고 시료가 사출되는 다이 $(\mathrm{die})$ 로 구성되어 있다.

고속압출기의 조건 변수에 따른 Chlorella sp.의 가수분 해 효율을 알아보기 위하여, 수분함량이 $15 \%$ 범위로 조절 된 Chlorella sp. 시료 $10 \mathrm{~g}$ 을 사용하여 가수분해를 실시하였 으며, 배럴 온도는 $45,50,55,60,65^{\circ} \mathrm{C}$ 로 조절하였다. 강한 회전력에 의해 시료를 파쇄하는 스크루의 회전속도는 10 , $50,100,150,200 \mathrm{rpm}$ 으로 설정하여 고속압출기의 각 공정 변수에 따른 전처리 공정을 실시하였다.

\subsection{Chlorella sp.의 당 성분의 분석}

Chlorella sp. 내에 존재하는 당 성분의 분석을 위해서, 고속 압출 전처리 공정을 통해 얻어진 가수분해물을 HPLC (Waters 510, Waters, Milford, MA, USA, RI-detector (Waters 410)) 를 이용하여 분석을 실시하였고, 컬럼은 Carbohydrate analysis column $(300 \times 7.8 \mathrm{~mm}$, Aminex HPX-87P, BIO-RAD, USA) 을 사용하였으며, 이동상으로는 $100 \%$ 증류수를 $70^{\circ} \mathrm{C}$ 에서 $0.6 \mathrm{~mL} / \mathrm{min}$ 유속으로 흘려 30 분 동안 분석하였다.

\section{4. 고속압출 전처리 잔유물의 효소처리}

고속압출기를 통해 사출된 가수분해물을 제외한 잔여물을 건조시킨 후 1,3,5 FPU/g 역가의 cellulase (Cellubrix L, 96 IU FPA $/ \mathrm{mL}$; Novozyme A/S, USA)와 100, 150, 200 Unit $/ \mathrm{mL}$ 의 역가의 amyloglucosidase (Sigma aldrich, USA) 처리를 실시하였다. 건조된 잔유물을 $55^{\circ} \mathrm{C}$ 에서 $150 \mathrm{rpm}$ 으로 sodium acetate buffer 용액 (pH 4.8) $100 \mathrm{~mL}$ 에 48시간동안 반응 시 키고 일정 시간간격을 두고 sampling하며, 전처리 잔유물 내 단당류로 가수분해된 에탄올용 글루코오스의 함량을 HPLC (Waters 510, Waters, Milford, MA, USA, RI-detector (Waters 410))를 이용하여 측정하였고, 컬럼은 Carbohydrate analysis column $(300 \times 7.8$ mm, Aminex HPX-87P, BIO-RAD, USA $)$
을 사용하였으며, 이동상으로는 $100 \%$ 증류수를 $70{ }^{\circ} \mathrm{C}$ 에서 $0.6 \mathrm{~mL} / \mathrm{min}$ 유속으로 흘려 30 분 동안 분석하였다 [28].

\section{5. 가수분해물의 에탄올 발효}

가수분해물의 에탄올 생산성 검증을 위하여 $500 \mathrm{~mL}$ 플라 스크에서 발효실험을 실시하였다. 종균은 Saccharomyces cerevisiae (ATCC, 24858)을 사용하였고, YPD (yeast extract $1 \%$, peptone $2 \%$, glucose $2 \%$ ) 배지를 이용해 shaking incubator $\left(30^{\circ} \mathrm{C}, 150 \mathrm{rpm}\right)$ 에서 48 시간 동안 배양하였다. 플라스크 배양을 위해 기본 YPD 배지에서 글루코오스를 대신하고 최적조건 가수분해 당화물 $100 \mathrm{~mL}$ 에 yeast extract $1 \%$, peptone $2 \%$ 를 넣어 제조하였다. 배지의 $\mathrm{pH}$ 는 $\mathrm{NaOH}$ 를 이 용하여 5.5 로 맞추며 $5 \mathrm{~mL}$ (배양부피 $10 \%$ )의 종균을 접종하 였다. 배양액의 에탄올 함량 측정을 위해 Gas chromatography (HP-5890, Agilant, USA)를 이용하여 분석하였다. Flame Ionization Detector (FID)를 이용하여 오븐온도를 $150^{\circ} \mathrm{C}$, injector와 FID 온도는 $250^{\circ} \mathrm{C}$ 로 조절하였다. $\mathrm{N}_{2}$ 를 carrier gas로 이용하였으며 $50 \mathrm{~mL} / \mathrm{min}$ 속도로 조절하여 컬럼은 INNOWax column $(30 \mathrm{~m} \times 0.32 \mathrm{~mm}$, Agilant 19091N-113)을 사용하였다 [29].

\subsection{Variable Pressure Field Emission Scanning Electron Microscopy (VP-FE-SEM)을 통한 Chlorella sp.의 입자 표면 관찰}

고속 압출 전처리 공정을 통한 Chlorella sp.의 전처리 전, 후 의 입자 표면의 관찰을 위해 전계방출형 주사전자현미경 (ZIESS, Variable Pressure Field Emission Scanning Electron, SUPRA 55VP, Germany)으로 관찰하였다. Variable Pressure Field Emission Scanning Electron Microscope (VP-FE-SEM) 은 금, 백금 등을 이용해 입자를 3 4 mm정도 얇게 증착하는 전처리 과정을 거친 후, 고속 압출 전처리 공정을 통해 제조 한 Chlorella sp.의 입자 표면의 형태를 관찰하였다.

\section{3. 결과 및 고찰}

\subsection{Chlorella sp.의 고속압출기를 이용한 가수분해}

Fig. 1은 시료의 수분함량과 압출기의 배럴 온도 그리고 스 크루의 회전 속도 변수에 따른 글루코오스의 전환 수율을 반응표면분석법을 통해 나타내었다. 압출기의 배럴 온도 범위 는 $45 \sim 65^{\circ} \mathrm{C}$ 까지 $5^{\circ} \mathrm{C}$ 간격으로 설정하였고, 시료의 수분함량 은 $15 \%$ 로 설정하였으며 스크루 회전속도는 10 200 rpm으 로 $50 \mathrm{rpm}$ 간격을 두고 변수를 추가 설정함으로써, 배럴의 온도와 스크루의 회전 속도에 따른 최대 글루코오스의 전환 수율을 얻을 수 있는 공정 변수 조건을 탐색하였다.

Table 2는 공정 변수에 따른 글루코오스 전환 수율을 나타 낸 결과이다. 표에서 알 수 있듯이 Chlorella sp.로부터 얻을 수 있는 최대 글루코오스 전환 수율은 시료의 수분함량이 $15 \%$ 이고, 고속 압출기의 배럴 온도가 $55^{\circ} \mathrm{C}$ 이며 스크루의 회 전속도가 $100 \mathrm{rpm}$ 으로 최적화 되었을 때 $13.24(\%, \mathrm{w} / \mathrm{w})$ 로 나타났다. 글루코오스로의 전환 수율에 미치는 배럴 온도의 
(a)

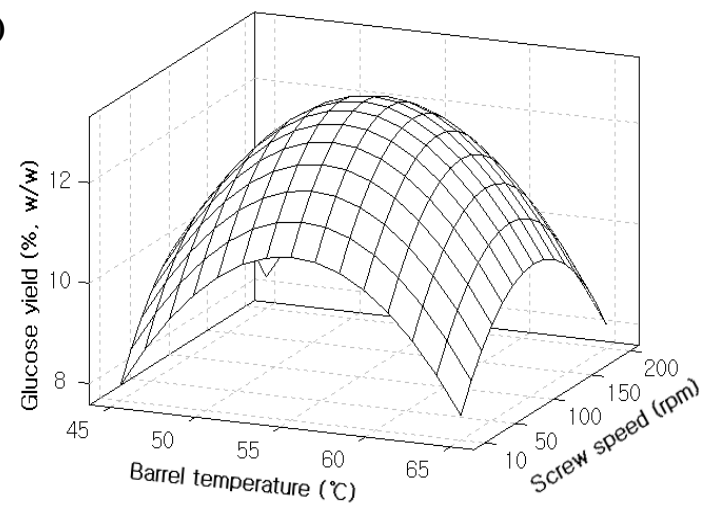

(b)

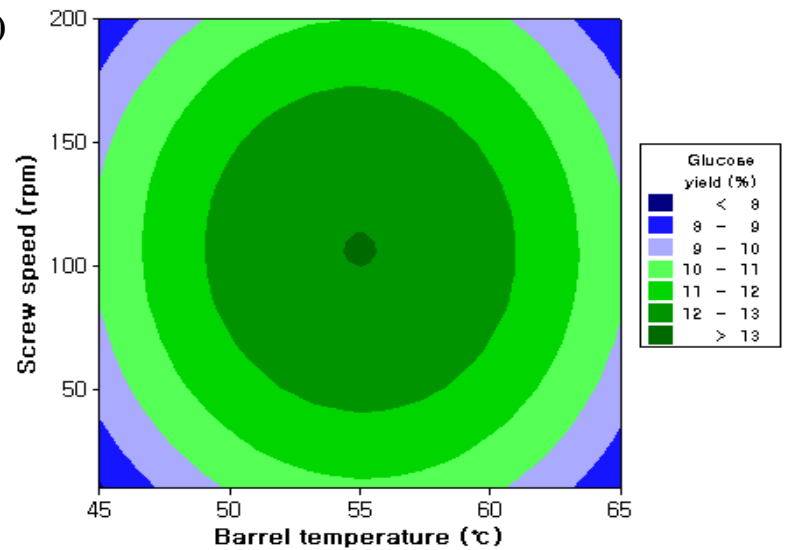

Fig. 1. Glucose conversion yield of high speed extrusion process according to barrel temperature and moisture content from Chlorella sp..

Table 2. Glucose conversion yield from Chlorella sp. of high speed extrusion process according to barrel temperature and screw speed

\begin{tabular}{ccc}
\hline $\begin{array}{c}\text { Screw speed } \\
(\mathrm{rpm})\end{array}$ & $\begin{array}{c}\text { Temperature } \\
\left({ }^{\circ} \mathrm{C}\right)\end{array}$ & $\begin{array}{c}\text { Glucose yield } \\
(\%, \mathrm{w} / \mathrm{w})\end{array}$ \\
\hline & 45 & 8.0 \\
10 & 50 & 10.38 \\
& 55 & 10.88 \\
& 60 & 9.74 \\
& 65 & 8.71 \\
\hline 50 & 45 & 9.88 \\
& 50 & 11.38 \\
& 55 & 12.77 \\
& 60 & 11.01 \\
& 65 & 10.11 \\
\hline & 45 & 10.23 \\
& 50 & 11.79 \\
& 55 & 13.24 \\
& 60 & 11.64 \\
& 65 & 10.68 \\
\hline \multirow{3}{*}{150} & 45 & 9.57 \\
& 50 & 11.23 \\
& 55 & 12.21 \\
& 60 & 10.77 \\
& 65 & 9.72 \\
\hline & 45 & 8.25 \\
& 50 & 10.96 \\
& 55 & 11.53 \\
& 65 & 10.18 \\
& & 9.17 \\
\hline & &
\end{tabular}

영향은 $45 \sim 55^{\circ} \mathrm{C}$ 까지는 증가하는 경향을 나타냈으며, 55 $65^{\circ} \mathrm{C}$ 범위에서는 온도의 증가에 따라 유의적으로 감소하는 경향을 나타냈다. 배럴의 온도가 증가함에 따라 Chlorella $\mathrm{sp}$. 가 갖는 세포 조직의 변화가 일어나 $55^{\circ} \mathrm{C}$ 에서는 그 정도 가 가장 심해 글루코오스의 용출이 효율적으로 이루어진 것 으로 사료된다. 특히, 배럴 온도가 $45^{\circ} \mathrm{C}$, 스크루 회전속도가 $10 \mathrm{rpm}$ 일 경우 $8.0(\%, \mathrm{w} / \mathrm{w})$ 로 가장 낮은 글루코오스 전환 수율을 나타냈는데, 이는 시료가 갖는 수분함량으로 인해 비기계적 에너지 투입량이 감소하여 Chlorella sp.의 세포벽 파괴가 효율적으로 이루지지 못해 글루코오스의 용출이 감 소하는 것으로 판단된다 [32,33]. 또, 스크루의 회전속도가 증가함에 따라 글루코오스의 전환 수율이 감소하는 경향을 나타냈다. 이는 스크루의 회전 속도가 증가하면서 시료가 주입구부터 배출구까지 머무는 시간이 짧아져 스크루의 회 전에 의한 물리적인 힘인 마찰력과 전단력을 충분히 공급 받지 못한 것으로 사료되며, 이와 같은 결과는 2 세대 바이 오매스인 옥수수대를 시료로 하여 고속 압출 전처리 공정을 실시한 결과와 유사한 경향을 나타냈다 [11].

상기 결과로부터 이전 연구를 통해 2세대 바이오매스인 옥수수대를 화학적 물질인 황산을 이용한 전처리 공정을 실 시함으로써 얻은 글루코오스 전환 수율이 약 $4.5(\%, \mathrm{w} / \mathrm{w})$ 로 보고되어진바 있다. 이를 비교해 볼 때, 3 세대 바이오매 스로써 미세조류인 Chlorella sp.를 고속 압출 전처리를 통 해 얻어진 글루코오스 전환 수율은 옥수수대로부터 전환된 글루코오스 수율보다 약 $6.5(\%, \mathrm{w} / \mathrm{w})$ 높은 수율을 나타냈 다 [30,31]. 2세대 바이오매스 이외에도 3 세대 바이오매스인 미세조류를 이용한 다양한 전처리 공정을 통해 얻을 수 있는 글루코오스의 전환 수율을 Table 3 에 나타냈다. 고속 압출 공정을 통해 얻어진 최대 글루코오스 전환 수율은 $13.24 \%$, $\mathrm{w} / \mathrm{w})$ 이며, Table 3 에 제시된 미세조류 Chlorella vulgaris와 Scenedesmus obliquus 의 황산 전처리 공정을 통한 글루코 오스 전환 수율은 각각 $14.0(\%, \mathrm{w} / \mathrm{w}), 14.7(\%, \mathrm{w} / \mathrm{w})$ 로 고 속 압출 전처리 공정과 큰 차이를 보이지 않았다. 결과적으 로 고속 압출 공정은 화학적인 전처리를 실시하지 않고도 오직 물만을 사용하면서도 높은 글루코오스 전환 수율을 나 타냄으로써 물만을 사용하는 기존의 공정에서 낮게 나타나 는 글루코오스 전환 수율을 보완할 수 있음을 증명했다.

화학적인 전처리 공정 이외에도 물리적인 전처리를 통한 연구결과를 보면, 고압 액화 전처리 공정을 통한 거대조류인 구멍갈파래로부터 최대 글루코오스 전환 수율이 $11.2 \%$, $\mathrm{w} / \mathrm{w})$ 로 나타났는데 이와 같은 결과는 고속 압출 전처리 공정 과 비슷한 글루코오스 전환 수율을 나타냄으로써 고속 압출 전처리 공정 또한 물을 사용하면서 높은 글루코오스 전환 수율을 나타내는 효과적인 공정으로 바이오 에탄올 생산에 적용할 수 있음을 확인했다 [29]. 또, 녹조류에 속하는 미세 조류인 Chlorococum humicola를 초음파 전처리 공정을 수행 한 결과에서는 최대 글루코오스 전환 수율이 $15.2(\%, \mathrm{w} / \mathrm{w})$ 로 나타났다. 고속 압출 공정을 통해 얻을 수 있는 최대 글 루코오스 전환 수율보다는 약 $2(\%, \mathrm{w} / \mathrm{w})$ 높은 결과를 나타 냈는데, 이러한 원인은 미세조류의 종에 따른 세포벽의 구 성성분 및 세포내 저장된 당류의 성분비의 차이에 기인하는 
Table 3. Comparison of conversion yields of glucose after pretreatment from microalgae under various pretreatment conditions

\begin{tabular}{|c|c|c|c|}
\hline \multirow{2}{*}{ Method } & \multirow{2}{*}{ Sample } & Pretreatment yield & \multirow{2}{*}{ Reference } \\
\hline & & Glucose $(\%, w / w)$ & \\
\hline High speed extrusion pretreatment & Chlorella sp. & 13.24 & This paper \\
\hline Sulfuric acid hydrolysis pretreatment* & Chlorella vulgaris & 14.0 & [34] \\
\hline Sulfuric acid hydrolysis pretreatment** & Scenedesmus obliquus & 14.7 & {$[35]$} \\
\hline Ultrasoication $* * *$ & Chlorococum humicola & 15.2 & {$[36]$} \\
\hline
\end{tabular}

*The Chlorella vulgaris for acid hydrolysis pretreatment condition such as $5 \% \mathrm{H}_{2} \mathrm{SO}_{4}$ at $120^{\circ} \mathrm{C}$ - over $30 \mathrm{~min}$.

**The Scenedesmus obliquus for acid hydrolysis pretreatment condition such as $5 \% \mathrm{H}_{2} \mathrm{SO}_{4}$ at $120^{\circ} \mathrm{C}$ - over $30 \mathrm{~min}$.

***The Chlorococum humicola for ultrasonication pretreatment condition such as a frequency of $40 \mathrm{kHz}$, acoustic power up to $130 \mathrm{~W}$ and batch mode at $100 \%$ power levels for $25 \mathrm{~min}$.

것으로 사료된다.

(a)

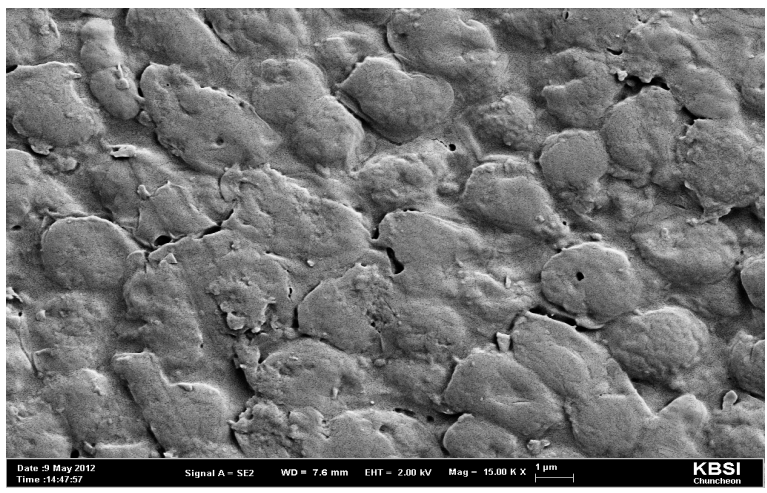

(b)

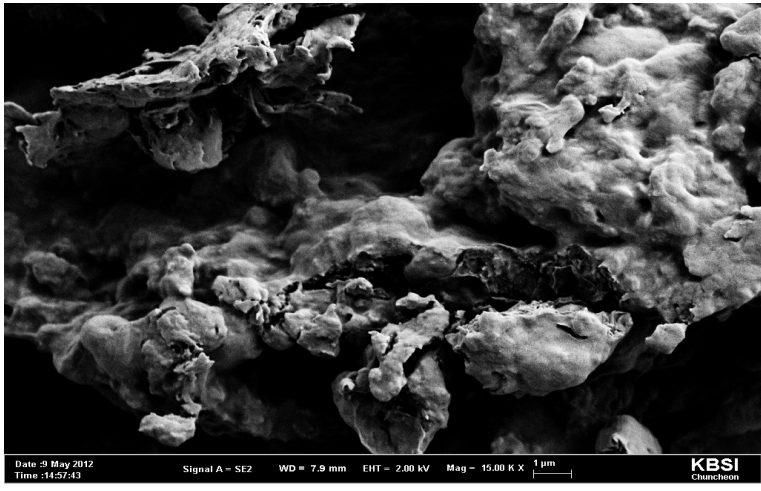

Fig. 2. Observation of FE-SEM (Field Emission Scanning Electron Microscope) of Chlorella sp. before and after extraction. High speed extrusion process: (a) Control sample (before pretreatment), (b) High speed extrusion process at $55^{\circ} \mathrm{C}, 15 \%$ moisture content and $50 \mathrm{rpm}$ (after pretreatment).

고속 압출 전처리 공정으로부터 효율적인 Chlorella sp. 의 파쇄가 이루어졌는지를 확인하고자 FE-SEM를 통해 Chlorellasp.의 세포 표면을 관찰하였으며, 결과를 Fig. 2에 나타내었다. Fig. 2 와 같이 전처리 전, 후의 Chlorella sp. 표 면의 구조가 확연히 차이를 나타냈는데, 특히, 전처리 후의 세포 표면 형태는 Fig. 2(a)와 같이 둥근 모양의 세포 형태를 띠지 않고, Fig. 2(b)와 같이 형태를 알아볼 수 없을 정도로 세포가 찌그러지거나 세포구조가 무너진 형태의 결과를 나 타냈다. 상기 결과로 미루어 보아, 고속 압출 전처리 공정에 서 작용하는 강한 전단력 및 마찰력에 의해 Chlorella sp.의 세포벽골격을 이루는 다당류인 셀룰로오스가 분해되어 세포
의 표면 형태가 불분명하게 파쇄된 것으로 사료되며, 이와 같은 결과를 통해 고속 압출 전처리 공정은 Chlorella sp.의 세포벽을 효율적으로 가수분해시킴으로써 세포벽의 셀룰로 오스와 세포내부에 저장된 전분으로부터 발효가능한 당인 글루코오스로의 용출을 용이하게 함으로써 바이오 에탄올 생산에 효과적인 공정이라 판단된다.

따라서, 고속 압출기 전처리 공정을 통한 Chlorella sp.로 부터 글루코오스의 생산은 기존에 연구되어진 고압 액화, 고 압 균질화 전처리 공정에 비해 전처리 공정에 소비되는 에너 지를 낮추어 고효율의 당화물을 생산할 수 있으며, 화학적 전처리없이 물만을 이용하여 글루코오스를 생산함으로써 경제적이고 게다가 낮은 온도에서 공정을 실시함으로써 발 효저해물질 (HMF)의 생성을 줄일 수 있어 고효율의 바이오 에탄올 생산이 가능한 전처리 공정으로 적용이 가능하다.

\section{2. 전처리 잔유물의 효소 당화 공정}

고속 압출 전처리 공정을 통해 얻어진 Chlorella sp.의 잔유 물을 cellulase와 amyloglucosidase를 이용하여 효소 처리 공정을 수행한 결과를 Fig. 3 에 나타내었다. 전처리 조건은 최적합 조건인 $55^{\circ} \mathrm{C}$ 의 배럴온도, $15 \%$ 의 수분함량 그리고 $100 \mathrm{rpm}$ 의 스크루 회전속도를 적용하여 전처리한 Chlorella sp. 의 잔유물을 이용하여 효소의 역가별로 효소 당화도를 측정 하였다. 세포벽을 구성하는 주성분인 셀룰로오스는 cellulase 효소를 이용하여 단당류인 글루코오스로의 전환이 가능하며, 세포내 저장 다당류인 전분은 amyloglucosidase를 이용하여 글로코오스로의 전환이 가능하므로, 본 연구에서 이 효소들 을 처리하였을 경우의 결과는 다음과 같다. Chlorella sp.가 갖는 $21.35(\%, \mathrm{w} / \mathrm{w})$ 의 총 탄수화물 중 셀룰로오스의 함량 $35.28(\%, \mathrm{w} / \mathrm{w})$ 로부터 cellulase를 이용해 당화 공정을 실시 한 결과 압출기를 이용한 전처리 공정에서 생성된 글루코오 스 $13.24(\%, \mathrm{w} / \mathrm{w})$ 를 제외한 나머지로부터 $14.35(\%, \mathrm{w} / \mathrm{w})$ 의 총 탄수화물에 대한 글루코오스 전환 수율을 나타냈다. 이 때, 셀룰로오스로부터 효소 당화 공정을 거쳐 전환된 글루 코오스의 수율은 $64(\%, w / w)$ 를 나타냈다. Fig. 3 의 결과와 같이 cellulase를 이용한 Chlorella sp. 의 효소 당화 공정에서 글루코오스 전환 수율의 증가폭은 20 시간까지 급속도로 상 승하였으며, 그 이후부터는 효소당화력이 낮아져 전환 수율 의 증가폭이 둔화되는 것으로 판단된다. Amyloglucosidase 를 사용하여 Chlorella sp. 내부에서 용출된 전분을 가수분해 했을 경우에는 $150 \mathrm{Unit} / \mathrm{mL}$ 의 역가에서 전분으로부터 최대 
Table 4. The glucose conversion yield from cellulose and starch through enzymatic hydrolysis after high speed extrusion pretreatment

\begin{tabular}{cccc}
\hline Polysacchride & Composition $(\%, \mathrm{w} / \mathrm{w})$ & Enzymatic hydrolysis yield $(\%, \mathrm{w} / \mathrm{w})$ & Glucose conversion yield $(\%, \mathrm{w} / \mathrm{w})$ \\
\hline Cellulose & 35.28 & 64.0 & 14.35 \\
Starch & 20.52 & 40.0 & 9.46 \\
\hline
\end{tabular}

$40(\%, \mathrm{w} / \mathrm{w})$ 의 효소 당화 공정 수율을 보였으며, 총 탄수화 물로부터 글루코오스의 전환 수율은 $9.46(\%, w / w)$ 를 나타 냈다. Amyloglucosidase는 cellulase와 달리 전체적으로는 24 시간까지 효소 반응이 증가하지만 처음 16 시간까지 전환 수율의 증가폭이 급격히 증가하는 경향을 보이나, 그 이후 부터는 모든 효소 역가에서 전환 수율의 증가폭이 둔화되었 음을 확인하였다. 이처럼 두 효소가 작용하여 글루코오스로 전환하는 경향은 비슷하나 효소 당화 시점이 다름을 확인하 였으며, amyloglucosidase를 이용한 효소당화에서 전환 수율 이 $40(\%, \mathrm{w} / \mathrm{w})$ 로 낮은 이유는 압출기를 이용한 전처리 공 정을 통해서 Chlorella sp.가 갖는 전분이 완전히 분해되지 않 아 전환 수율이 낮아진 것으로 사료된다. 그에 반해 cellulase 를 이용한 효소당화에서는 약 $64(\%, \mathrm{w} / \mathrm{w})$ 로 세포벽이 갖는 셀룰로오스가 충분히 분해되었으며, 이는 압출기를 통한 물 리적인 파쇄가 효율적으로 작용한 것으로 사료된다. 특히, 본 압출 전처리 공정을 적용했을 경우 1 5 FPU/glucan까지 cellulase를 투입하였을 경우에서 모든 농도에서 $60 \%$, $\mathrm{w} / \mathrm{w}$ ) 이상의 글루코오스 전환 수율을 나타낸 것으로 보아 $1 \mathrm{FPU} /$ glucan의 낮은 효소투입농도로도 충분히 글루코오스 의 전환 수율이 가능함을 확인했다.

(a)

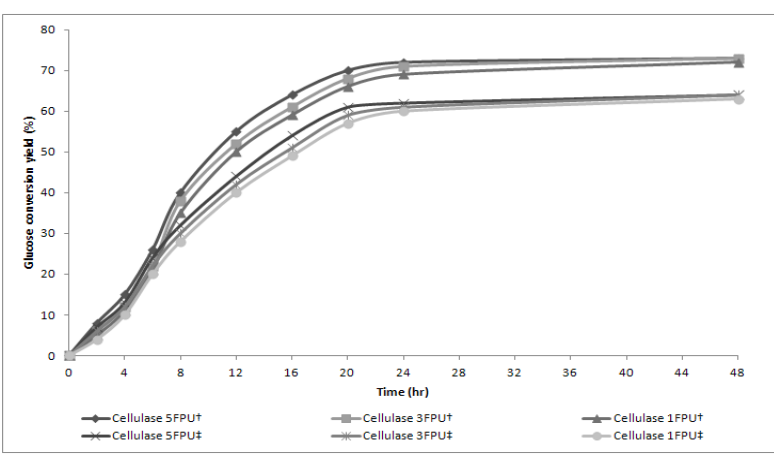

(b)

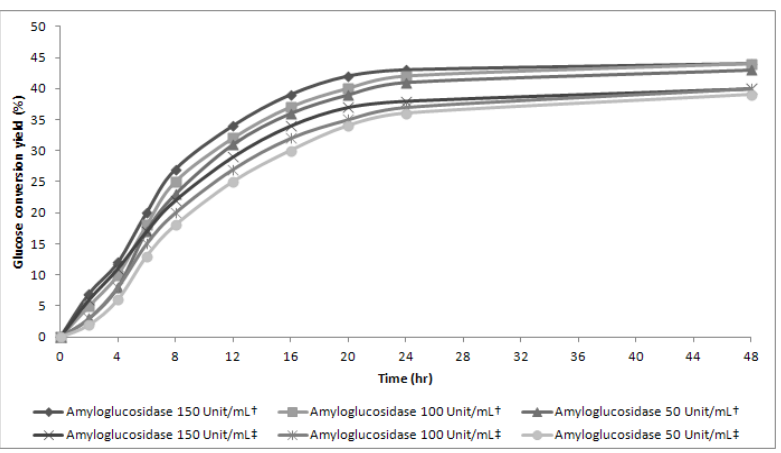

Fig. 3. Glucose conversion yield through enzyme treatment (cellulase and amyloglucosidase) from Chlorella sp.. (a) Cellulase enzyme treatment $(\dagger$ : high speed extrusion process, $\ddagger$ : $1 \%$ sulfuric acid hydrolysis pretreatment), (b) Amyloglucosidase enzyme treatment ( $\dagger$ : high speed extrusion process at $55^{\circ} \mathrm{C}$ and $50 \mathrm{rpm}$ screw speed, †: $1 \%$ sulfuric acid hydrolysis pretreatment at $120^{\circ} \mathrm{C}$ over $30 \mathrm{~min}$ ).
Table 4는 Chlorella sp.가 갖는 전분 및 셀룰로오스의 함량을 효소 당화 공정의 수율과 그로 인해 생성되는 글 루코오스의 전환 수율을 나타낸 결과이다. Chlorella sp.가 갖는 탄수화물 중 다당류인 셀룰로오스와 전분의 함량은 각각 $35.28(\%, \mathrm{w} / \mathrm{w}), 20.52(\%, \mathrm{w} / \mathrm{w})$ 이며, 이를 고속 압출 공정과 효소 당화 공정을 거친 후 전환되는 총 탄수화물에 대한 글루코오스의 전환 수율은 각각 $14.35(\%, \mathrm{w} / \mathrm{w}), 9.46$ $(\%, \mathrm{w} / \mathrm{w})$ 을 얻을 수 있었다. 이와 같은 결과는 효소 당화 공정을 통해 다당류가 단당류인 글루코오스로 효율적으 로 전환될 수 있음을 알 수 있으며, 고속 압출 공정을 통해 Chlorellasp.의 단단하고 다중층으로 이루어진 세포벽 구 조가 스크루의 회전에 의한 마찰력과 전단력, 시료가 가 진 수분함량에 따른 비기계적 에너지 투입량 그리고 배럴 온도에 의해 파쇄되어 셀룰로오스로부터 포도당의 전환을 가능하게 하며, 세포벽의 파쇄로 인한 세포내 저장물질인 전분의 용출을 용이하게 함으로써 효소와의 효율적인 반응 을 통해 높은 수율의 글루코오스 전환이 이루어진 것으로 사료된다.

\section{3. 가수분해물의 에탄올 발효}

Chlorella sp. 고속 압출 전처리 및 효소 당화 공정을 거쳐 얻 어진 가수분해물인 글루코오스를 에탄올 발효 시킨 결과를 Fig. 4에 나타내었다. 글루코오스에서 배양초기 8시간 동안은 효모가 글루코오스를 급격히 소모하였으며, 8시간 이후부 터는 효모로부터 바이오에탄올 생성량이 급증하였다. 24시 간 이후에는 에탄올의 생성 속도가 둔화되는 경향을 나타내 는데, 이는 배지 내에 남아있는 글루코오스의 양을 대부분 소모하였기 때문인 것으로 판단되며, 이 때, 바이오 에탄올 은 $3.3 \mathrm{~g} / \mathrm{L}$ 가 생성되었다. 이 결과, Chlorella sp.의 글루코 오스로부터 생성할 수 있는 에탄올의 생성 수율은 약 42 $(\%, \mathrm{w} / \mathrm{w})$ 로 나타났다. 글루코오스를 기질로 하여 효모로 부터 생성할 수 있는 이론적 에탄올 생성 수율은 $50(\%$, $\mathrm{w} / \mathrm{w})$ 로 보고되고 있는데, 이론적 수율에 거의 근접하는 결 과를 나타낸 것으로 미루어 보아, 고속 압출 전처리 공정 의 적용 시 화학적 물질 대신 물을 사용하고, $200^{\circ} \mathrm{C}$ 이상의 고온 가수분해 대신 $50 \sim 65^{\circ} \mathrm{C}$ 범위의 저온 가수분해를 실시 하게 됨으로써 발효저해물질인 $\mathrm{HMF}$ 의 생성 농도가 낮기 때문으로 사료된다 [25,29]. 바이오 에탄올 생성을 위한 발효 공정에서 발효저해물질 (HMF)의 생성은 가장 큰 문제점 중 하나이다. 그러나, 본 연구에서 적용한 고속 압출 전처리 공정에서는 화학적인 전처리와 물리적인 전처리에 의한 발 효저해물질 (HMF)의 생성을 줄이기 위해 오직 물만을 사용 한 전처리 공정을 수행함으로써 높은 수준의 에탄올 생산 과 동시에 발효저해물질 (HMF)의 생성 농도 또한 낮출 수 있어 경제성, 효율성, 안정성 면에서 타 공정들에 비해 우수 한 것으로 판단된다. 


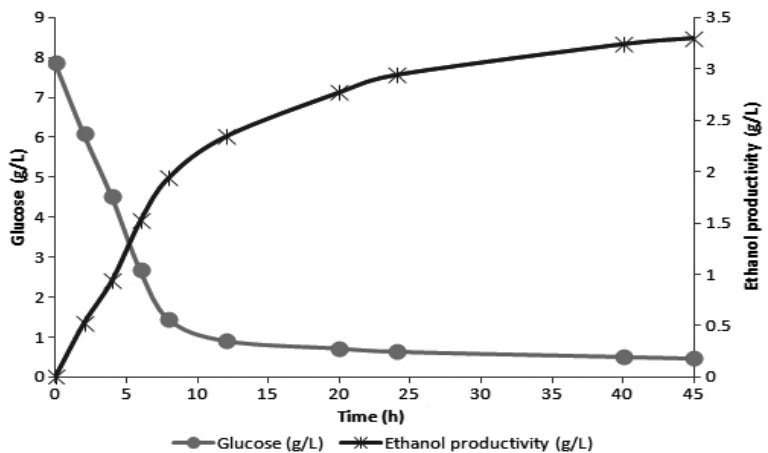

Fig. 4. Concentration of bioethanol through high speed extrusion process at $55^{\circ} \mathrm{C}$ and $100 \mathrm{rpm}$ screw speed from Chlorella sp..

\section{4. 결론}

현재 미세조류를 이용한 바이오에너지 개발은 바이오 디젤에 초점을 두고 진행되고 있으나, 미세조류의 생화학적으로 지질 뿐만 아니라 탄수화물 또한 다량을 함유하고 있으므로 미세 조류를 활용한 바이오 에탄올 생산에 대한 연구도 시급한 실정이다. 따라서 본 연구에서는 해양미세조류은 Chlorella $\mathrm{sp}$.로부터 효율적인 바이오 에탄올 생산을 위해서 고속 압출 전처리 공정을 적용하여 연구를 수행하였다. Chlorella sp. 로부터 얻을 수 있는 최대 글루코오스의 전환 수율은 압출 기의 배럴 온도가 $55^{\circ} \mathrm{C}$, 시료의 수분함량이 $15 \%$ 그리고 스크 루의 회전속도가 $100 \mathrm{rpm}$ 인 최적 조건에서 $13.24(\%, \mathrm{w} / \mathrm{w})$ 의 전환 수율을 얻을 수 있었다. 또한, 전처리 잔유물을 이 용한 효소 처리 공정에서 cellulase와 amyloglucosidase 효 소의 최대 글루코오스 전환 수율은 각각 $5 \mathrm{FPU} /$ glucan, $150 \mathrm{Unit} / \mathrm{mL}$ 역가에서 $64(\%, \mathrm{w} / \mathrm{w})$ 와 $40(\%, \mathrm{w} / \mathrm{w})$ 로 나타 났는데, 이는 저역가의 효소농도로도 충분한 가수분해 효율 을 보이는 것으로 바이오 에탄올을 대량 생산 할 경우, 효소 처리 공정에 소비되는 비용을 절감 할 수 있어 경제적으로 유리할 것으로 판단된다. 생성된 글루코오스를 기질로 하여 Saccharomyces cerevisiae를 이용한 에탄올 발효 공정에서 는 이론적 에탄올 생성 수율인 $50(\%, w / w)$ 에 근접하는 약 $42(\%, w / w)$ 의 에탄올 생성 수율을 보임으로써, 고효율의 바 이오 에탄올 생산이 가능함을 입증하였다. 특히, 고속 압출 전처리 공정에서는 화학적 처리없이 물만을 사용하고, 낮은 온도에서 전처리를 실시하기 때문에 에탄올 발효시 영향을 미치는 요인인 발효저해물질 (HMF)의 생성을 최소화시킴으 로써 이론적 에탄올 생성 수율에 근접하는 결과를 얻었다. 따라서, 본 연구에서 실시한 Chlorella sp.로부터 고속 압 출 전처리 공정을 적용한 에탄올 생산 공정은 효율적인 공정 으로 판단되며, 본 연구를 통해 최적화 전처리 공정의 도입 으로 미세조류로부터 고수율의 바이오 에탄올 생산이 가능 할 것으로 판단된다.

\section{감사}

본 연구는 한국해양과학기술원 (과제번호: PE98592)의 지원
으로 수행 되었기에 심심한 사의 표합니다.

\section{References}

1. Chisti, Y. (2008) Biodiesel from microalgae beats bioethanol. Trends. Biotechnol. 26: 126-131.

2. Saulnier, L., C. Marot, E. Chanliaud, and J. F. Thibault (1995) Cell wall polysaccharide interaction in maize bran. Carbohydr. Polym. 26: 279-287.

3. Miranda, J. R., P. C. Passarinho, and L. Gouveia (2012) Pretreatment optimization of Scenedesmus obliquus microalga for bioethanol production. Bioresource. Technol. 104: 342-348.

4. Singh, J. and S. Gu (2010) Commercialization potential of microalgae for biofuels production. J. Renew. Sustain. Ener. 14: 2596-2610.

5. Talbot, P., J. M. Thébault, A. Dauta, and J. de la Noüe (1991) A comparative study and mathematical modeling of temperature, light and growth of three microalgae potentially useful for wastewater treatment. Water Res. 25: 465-472.

6. Fernandes, B., G. Dragone, J. Teixeira, and A. Vicente (2010) Light regime characterization in an airlift photobioreactor for production of microalgae with high starch content. Appl. Biochem. Biotechnol. 161: 218-226.

7. Liu, Z. Y., G. C. Wang, and B. C. Zhou (2008) Effect of iron on growth and lipid accumulation in Chlorella vulgaris. Bioresource. Technol. 99: 4717-4722.

8. Huang, G., F. Chen, D. Wei, X. Zhang, and G. Chen (2010) Biodiesel production by microalgal biotechnology. Appl. Energy 87: 38-46.

9. Amaro, H. M., A. C. Guedes, and F. X. Malcata. (2011) Advances and perspectives in using microalgae to produce biodiesel. Appl. Energy. 88: 3402-3410.

10. Choi, S. P., M. T. Nguyen, and S. J. Sim (2010) Enzymatic pretreatment of Chlamydomonas reinhardtii biomass for ethanol production. Bioresource. Technol. 101: 5330-5336.

11. Yamada, T. and K. Sakaguchi (1982) Comparative studies on Chlorella cell walls: induction of protoplast formation. Arch. Microbiol. 132: 10-13.

12. Allard, B. and J. Templier (2000) Comparison of neutral lipid profile of various trilaminar outer cell wall (TLS)-containing microalgae with emphasis on algaenan occurrence. Phytochemistry 54: 369-380.

13. Atkinson, A. W., B. E. S. Gunning, and P. C. L. John. (1972) "Sporopollenin in the cell wall of chlorella and other algae: ultrastructure, chemistry, and incorporation of 14C-acetate, studied in synchronous cultures. Planta 107: 1-32.

14. Koo, S. Y., K. H. Cha, and D. U. Lee (2007) Effects of high hydrostatic pressure of foods and biological system. Food Sci. Ind. 40: 23-30.

15. Wikandari, R., R. Millati, S. Syamsiyah, R. Muriana, and Y. Ayuningsih (2010) Effect of furfural, hydroxymethylfurfural and acetic acid on indigeneous microbial isolate for bioethanol production. Agricultural J. 5: 105-109.

16. Palmqvist, E., B. Hahn-Hagerdal, M. Galbe, and G. Zacchi (1996) The effect of water-soluble inhibitors from steam-pretreated willow on enzymatic hydrolysis and ethanol fermentation. Enzym. Microb. Technol. 19: 470-476.

17. Martin, C., C. F. Wahlbom, M. Galbe, L. J. Jonsson, and B. Hahn-Hagerdal (2001) Preparation of sugarcane bagasse hydrolysates for alcoholic fermentation by yeasts. Enzym. 
Microb. Technol. 7: 361-367.

18. Karunanithy, C. and K. Muthukumarappan (2010) Influence of extruder temperature and screw speed on pretreatment of corn stover while varying enzymes and their ratios. Appl. Biochem. Bioethanol. 162: 264-279.

19. Fu, C. C., T. C. Hung, J. Y. Chen, C. H. Su, and W. T. Wu (2010) Hydrolysis of microalgae cell walls for production of reducing sugar and lipid extraction. Bioresource. Technol. 101: 8750-8754.

20. Woo, H. C., J. H. Lee, and J. I. Park (2008) Production of bio-energy from marine algae: status and perspectives. Korean Chem. Eng. Res. 46: 833-844.

21. Chu, F. E., J. L. Dupuya, and K. L. Webb (1982) Polysaccharide composition of five algal species used as food for larvae of the american oyster, Crassostrea Virginica. Aquaculture. 29: 241-252.

22. Gray, K. A., L. Zhao, and M. Emptage (2006) Bioethanol. Curr. Opin. 10: 141-146.

23. Diaz, M. J., C. Cara, E. Ruiz, I. Romero, M. Moya, and E. Castro (2010) Hydrothermal pre-treatment of rapeseed straw. Bioresource Technol. 101: 2428-2435.

24. Kumar, S., U. Kothari, L. Kong, Y. Y. Lee, and R. B. Gupta (2011) Hydrothermal pretreatment of switchgrass and corn stover for production of ethanol and carbon microspheres. Biomass Bioenerg. 35: 956-968.

25. Fang, Z., T. Sato, R. L. Smith-Jr, H. Inomata, K. Arai, and J. A. Kozimski (2008) Reaction chemistry and phase behavior of lignin in high-temperature and supercritical water. Bioresource Technol. 99: 3424-3430.

26. Zhang, S., J. Zhu, and C. Wang (2004) Novel high pressure extraction technology. Int. J. Pharmaceut. 278: 471-474.

27. Guillard, R. R. L. (1975) Culture of phytoplankton for feeding marine invertebrate. pp. 296-360. In: W. L. Smith and M. H. Chanley (eds.). Culture of Marine Invertebrates Animals. Plenum, New York, USA.
28. Linde, M., M. Galbe, and G. Zacchi (2008) Bioethanol production from non-starch carbohydrate residues in process stream from a dry-mill ethanol plant. Bioresource Technol. 99: 6505-6511.

29. Han, J. G., S. H. Oh, M. H Jeong, H. B. Seo, K. H. Jeong, and H. Y. Lee (2010) Enhancement of sacchrification yield of Ulva pertusa kjellman for ethanol production through high temperature liquefaction process. KSBB J. 25: 245-362.

30. Lishi, Y., Z. Hongman, C. Jingwen, L. Zengxiang, J. Qiang, J. Honghua, and H. He (2008) Dilute sulfuric acid cycle spray flow-through pretreatment of corn stover for enhancement of sugar recovery. Bioresource Technol. 100: 1803-1808.

31. Meuser, F. (1989) Technological aspects regarding specific changes to the characteristic properties of extrudates by HTST extrusion cooking. pp. 35-53. In: B. Van Lengerich and F. Kohler (eds.). Physical Properties of Foods. Elsevier Applied Science Pub., London, UK.

32. Choi, J. W., H. J. Lim, K. S. Han, H. Y. Kang, and D. H. Choi (2005) Characterization of degradation features and degradative product of poplar wood (populusalba $\times$ glandulosa) by flow type-supercritical water treatment. J. Kor. For. En. 24: 39-46.

33. Ryu, K. H. and B. S. Kim (2005) Properties of extracts from extruded root and white ginseng at different conditions. $J$. Korean Soc. Food Sci. Nutr. 34: 306-310.

34. Lee, J. W., S. J. Lee, Y. H. Oh, D. H. Kim, D. Y. Kwon, and C. G. Lee (2011) Converting carbohydrates extracted from marine algae into ethanol using various ethanolic Escherichia coli Strains. Appl. Biochem. Biotechnol. 164: 878-888.

35. Gouveia, L., J. R. Miranda, and P. C. Passarinho (2011) Pretreatment optimization of Scenedesmus obliquus microalga for bioethanol production. Bioresource Technol. 104: 342-348.

36. Halima, R., R. Harun, M. K. Danquaha, and P. A. Webleya (2011) Microalgal cell disruption for bioethanol production. Appl. Energy 91: 116-121. 